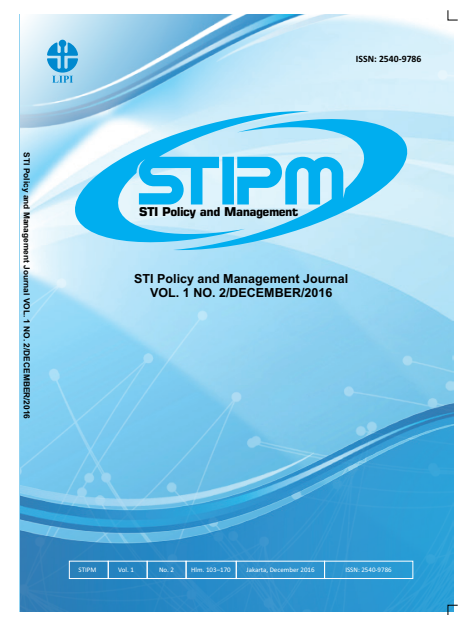

Journal of STI Policy and Management

Publication details, including instructions for authors and subscription information: http://www.stipmjournal.org/

\title{
How Does the Milk Processing Industry in Indonesia Develop Their Technological Capability?
}

\author{
Budi Triyono, Chichi Shintia Laksani, Muhammad Zulhamdani, \\ Saut Siahaan \\ Center for Science and Technology Development Studies - \\ Indonesia Institute of Sciences \\ Version of record first published: 15 December 2016
}

To cite this article: Triyono, B., Laksani, C. S., Zulhamdani, M. and Siahaan, S. (2016). How Does the Milk
Processing Industry in Indonesia Develop Their Technological Capability?. Journal of STI Policy and Manage-
ment, 1(2), 103-116
To link to this article: http://dx.doi.org/10.14203/STIPM.2016.54

ISSN 2540-9786 (Print); ISSN 2502-5996 (online)

Accreditation Number: 622/AU3/P2MI-LIPI/03/2015

Full terms and conditions of use: https://creativecommons.org/licenses/by-nc-sa/4.0/

You are free to:

- Share : copy and redistribute the material in any medium or format

- Adapt : remix, transform, and build upon the material

- The licensor cannot revoke these freedoms as long as you follow the license terms.

Under the following terms:

Attribution - You must give appropriate credit, provide a link to the license, and indicate if changes were made. You may do so in any reasonable manner, but not in any way that suggests the licensor endorses you or your use.

NonCommercial - You may not use the material for commercial purposes.

ShareAlike - If you remix, transform, or build upon the material, you must distribute your contributions under the same license as the original.

No additional restrictions - You may not apply legal terms or technological measures that legally restrict others from doing anything the license permits.

Notices:

- You do not have to comply with the license for elements of the material in the public domain or where your use is permitted by an applicable exception or limitation.

- No warranties are given. The license may not give you all of the permissions necessary for your intended use. For example, other rights such as publicity, privacy, or moral rights may limit how you use the material.

- If you copy the dataset merely to extract the uncopyrightable data elements would not need permission to do so. However, if you republish the full dataset or using the copyrightable data layers require a permission from PAPPIPTEK-LIPI. 


\title{
SCIENCE, TECHNOLOGY AND INNOVATION POLICY AND MANAGEMENT (STIPM) JOURNAL Volume 01, Number 02, December 2016
}

\author{
FOREWORD by EDITOR-in-CHIEF
}

We are very pleased to present the second issue of the Science, Technology and Innovation Policy and Management (STIPM) Journal. We are very excited that the journal has attracted papers from many countries. The variety of paper submissions has supported the international-level initiatives of the journal. Since the beginning of the year, a number of articles have been sent to us. Six articles are published in this issue, while others are still under the first or second phase of review and will follow in the subsequent issue.

In this issue, we present six articles on issues of technology and innovation development and policy at national-, regional-, and firm-level, written by scholars from Australia, Japan and Indonesia. The first article investigates the technological capability of the milk processing industry in Indonesia. The second article investigates mass production of innovation in the business model of start-up companies. The third article explores the diverse effects of four types of mobility on university entrepreneurship. The fourth article explores institutional transformations in local innovation systems used by the farmer community of Belu, East Nusa Tenggara, Indonesia. The fifth article analyzes the transition of bioplastic development in Indonesia, and the last article investigates the effectiveness of subsidies in technology adoption using the case study of reverse osmosis membrane technology in Mandangin Island, East Java, Indonesia. All articles have gone through editorial review by prominent experts.

I would like to thank the authors who have submitted articles to STIPM Journal for their trust, patience and timely revisions as well as for trusting Editor and Editorial Board. I encourage authors to submit their manuscripts. This scientific work is published widely on an open access policy.

My gratitude also goes to all members of the Editorial Board and reviewers who have contributed to this second issue, all of whom increase the quality of articles in this journal even more. We continue to welcome article submissions in the field of science, technology and innovation policy and management.

We wish you a 2017 Happy New Year!

Jakarta, December 2016

Editor-in-Chief 


\section{JOURNAL OF STI POLICY AND MANAGEMENT}

Volume 1, Number 2, December 2016

\section{LIST OF CONTENTS}

How Does the Milk Processing Industry in Indonesia Develop Their Technological Capability?

Budi Triyono, Chichi Shintia Laksani, Muhammad Zulhamdani, and Saut Siahaan $103-116$

Mass producing innovation: a case investigation on why accelerators might not be a paradox

Andrew Barnes

Exploring Diverse Effects of Four Types of Mobility on University Entrepreneurship

SatokoYasuda

Institutional Transformation of Local Innovation Systems in Farmer Community of Belu, East Nusa Tenggara

Febtri Wijayanti, Savitri Dyah, Rachmini Saparita, and Akmadi Abbas

Dynamics of Bioplastics Development in Indonesia

Qinan Maulana B. Soesanto, Dian Prihadyanti, Hartiningsih, and Trina Fizzanty.

Effectiveness of Subsidies in Technology Adoption: A Case Study Involving Reverse Osmosis (RO) Membrane Technology

Nur Laili, Rendi Febrianda, and Iin Surminah 163-170 



\title{
if STI POLICY AND MANAGEMENT \\ LIPI Journal homepage: http://www.stipmjournal.org
}

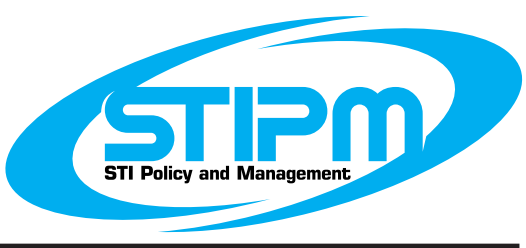

\section{How Does the Milk Processing Industry in Indonesia Develop Their Technological Capability?}

\author{
Budi Triyono, Chichi Shintia Laksani, Muhammad Zulhamdani, Saut Siahaan \\ Center for Science and Technology Development Studies - Indonesia Institute of Sciences
}

\begin{tabular}{|c|c|}
\hline ARTICLE INFO & ABSTRACT \\
\hline $\begin{array}{l}\text { Article History: } \\
\text { Received : } 28 \text { January } 2016 \\
\text { Revised : } 27 \text { November } 2016 \\
\text { Accepted : } 2 \text { December } 2016 \\
\text { Available online : } 15 \text { December } 2016\end{array}$ & $\begin{array}{l}\text { Increasing public awareness of the importance of milk consumption } \\
\text { and the increasing population of Indonesia have turned milk into } \\
\text { an economic commodity with strategic value. The purpose of } \\
\text { this study is to analyse the technological capability of the dairy } \\
\text { processing industry in Indonesia and to understand how companies }\end{array}$ \\
\hline $\begin{array}{l}\text { Keywords: } \\
\text { Technological capability } \\
\text { Technological learning } \\
\text { Dairy Industry }\end{array}$ & $\begin{array}{l}\text { build technological capability. This research was conducted through } \\
\text { case studies of some milk processing companies in Java whose } \\
\text { capital ownership is classified as either cooperative companies, local } \\
\text { companies or foreign companies. The results showed differences } \\
\text { in technological capabilities. The highest technological capability } \\
\text { was shown by foreign companies and large-scale local companies. } \\
\text { Meanwhile, the technological capability of dairy cooperatives is } \\
\text { still low. The categories of the technological capability development } \\
\text { mechanisms used by the two company types are also different. } \\
\text { Technological capability in dairy cooperatives consists of internal } \\
\text { efforts that do not involve external parties. Meanwhile, large-scale } \\
\text { local companies and foreign companies developed their technology } \\
\text { capabilities by involving external parties such as R\&D institutions } \\
\text { and foreign parties. }\end{array}$ \\
\hline
\end{tabular}

(C)2016 PAPPIPTEK-LIPI All rights reserved

\section{INTRODUCTION}

Research on technological capability has become relevant in relation to the milk processing industry in Indonesia for several reasons. First, increasing public awareness on the importance of milk consumption and increasing number of Indonesia's population have made milk as an economic commodity that has strategic value.

\footnotetext{
* Corresponding Author.

E-mail: budi_triyono012@yahoo.co.id
}

During the period of 2003-2013, milk consumption per capita in Indonesia fluctuated by about 5.85\% ('Centers and Agricultural Information', 2013). Even in the last few years, the growth rate demonstrated an increase. In 2008, the national milk consumption reached $9.51 \mathrm{~kg}$ per capita per year, which then increased to $14.26 \mathrm{~kg}$ per capita per year in 2011 through an average of $10 \%$ per year. However, the level of consumption is still far below other ASEAN countries. In 2009, the Directorate-General of Agro Industry and Chemistry at the Ministry of Industry noted that average 
milk consumption in the Philippines was $20 \mathrm{~kg}$ per capita per year, Malaysia $20 \mathrm{~kg}$ per capita per year, Thailand $20-25 \mathrm{~kg}$ per capita per year and Singapore $32 \mathrm{~kg}$ per capita per year. With increasing prosperity in Indonesian communities, the level of milk consumption can be expected to continue to rise closer to the level of consumption in other ASEAN countries. Meanwhile, milk production grew only by $1 \%$, from 827,000 tons in 2009 to 980,000 tons by 2013 (Ministry of Agriculture, 2013). The gap between the growths of consumption and that of the production has caused an increase in number of dairy imports in Indonesia. If these conditions are not controlled, then the gap could threaten the independence and sovereignty of food. Research by Morey (2011) reported an increase in the volume and value of imports of dairy products to meet the needs of milk consumption in Indonesia. In 2010, the volume of imports of dairy products increased by $12 \%$ since 2009 to 302,158 tons with a value of US\$ 925 million. The main imported products were skim milk powder, whole milk powder and whey.

Second, as part of the food industry, the dairy industry also has a great potential for development. In addition to potentially improving nutrition in the communities, the development of the dairy industry can also improve their well-being. This is due to the fact that the dairy industry can build the economy of citizens, particularly those who live in the village. Development of the dairy industry creates job opportunities, increases the income and welfare of ranchers and their families and even industry peers through increased production and productivity, as well as the added value and competitiveness of the manufacturing of farming yield. Data from the Ministry of Industry (2014) showed an increase in the value of production, the number of employment and added value in the dairy processing industry. The value of production during the period of 2006-2010 increased by $13 \%$, or an average increase of $3.25 \%$ per year, though the increase in production has not been able to offset the rise in the level of consumption. Employment in the milk processing industry also increased, although only by $7 \%$ from 9,483 in 2006 to 10,132 people in 2010 , or $1.75 \%$ per year. The increase also occurred in the value-added dairy processing industry by $11 \%$, or $2.75 \%$ per year.

Third, milk products have significant product diversification and any kind of processed milk product produced through the various stages of the production process requires the capability of process technology. The importance of the role of technology in the development of the industry (including in the processing industry of milk) is defined by some authors, such as one from Tjakraatmadja (1997) in Sunarharum \& Imam (2012), who states that technology is the basis for improving competence in company competitiveness. In addition, technology is also one of the key strategies in ensuring the sustainability of the company (Watanabe, 2004). The success of future business development requires an integrated strategic planning based on the primacy of technology (Kjellstrom, 2000; Sudaryanto, 2002). Further, Lopez-Salazar, LOpez-Mateo, and Ruben (2001) assert that the development of technological capability is a fundamental pillar for industry development as it raises the level of productivity, quality and efficiency in the use of resources, resulting in an improvement in production and processes. Value-added products and higher-level services make expansion into new markets possible, which in turn will increase industry competitiveness. Therefore, all companies would face hurdles before the repair capability of technology.

These points show the importance of the role of the dairy processing industry in meeting the needs of the community milk consumption of Indonesia, which currently still requires importation. In addition, the dairy processing industry is also expected to have a role in and contribute to the national economy. Therefore, research on the development of dairy processing industry technology capability in Indonesia has become important. The purpose of this paper is to analyze the technology capability of the milk processing industry in Indonesia and to understand how companies build their technological capability.

Studies on technological capability have been widely performed, not only in industrial countries but also in developing countries. Research on technological capability began by Fransman's 
(1984) description of technology capability in the third world. Lall $(1987,1992)$ discusses the factors that affect capability enhancement technology, especially in the manufacturing industry, i.e. the cement industry, the steel industry and the textile industry. Studies on technological capability were also carried out by Bell \& Pavit (1995), whose study explains that increase in technological capability depends on the five categories of companies, i.e. companies which are public suppliers (agro-industrial and textile), scale-intensive companies (automobile industry and steel), information-intensive companies (financial industry, sales, travel and publishing), science-based companies (industrial electronics, electrical and chemical), and specialized supplier firms (industrial capital goods, instruments and software).

Kim (1997) also discusses the capabilities of technology through the growth of the industry in South Korea, arguing that weak capability is mainly due to the inability of industrial technology to transfer technology. Basant \& Chandra (2002) examine the technological capabilities of the manufacturing industry in India, finding that companies use value chains to develop products and process technology. Hobday \& Rush (2007) have researched the improvement of technological capabilities in transnational corporations in developing countries, such as Thailand, in particular software companies. Hobday and Rush explain that a major factor in local capability development was the TNC's overall corporate strategy and, in particular, the way in which Thai subsidiaries fitted into global division of corporate. Rasiah (2009) discusses technological capability in the automotive industry in Indonesia and Malaysia. The study shows that technological capability is affected by trade regimes, policy, human resources, R\&D and process technology. Whitfield (2012) also conducted research on the development of agro-industrial technology on its capabilities in Ghana, finding that technology capability depended on the limitations of the company's expansion and the lack of competitiveness in the face of new competition. There is further research about technology capability in agro-industrial research by Lopez-Salazar et al (2001), which mapped out determinants of technological capability in the agribusiness sector in Mexico. The study approached technological capabilities from a resource-based view.

In all the studies mentioned above, there are three that are related to technology capability development in agro-industrial fields. As it is known, dairy products and their derivatives are the results of an agro-industry group. However, this study focuses on the improvement of technological capability in the national dairy industry only. The difference of this paper from other works of research is that studies that discuss technology capability in the dairy industry are yet to be found. Research on the national dairy industry has been conducted by Herawati and Priyanto (2013) in relation to the performance of dairy processing industry in supporting milk self-sufficiency in Indonesia. The study examines the performance of some parts of the dairy processing industry on the island of Java, as well as government policy in development of the dairy processing industry in Indonesia.

\section{ANALYTICAL FRAMEWORK}

This study uses two groups of key theories to guide empirical data analysis. The first group of theories relates to technological capability. It is important to explain or reveal the status of the company's technological capability in the dairy processing industry. The second group of theories relates to technological learning to explain how the companies accumulate technological capability.

Various scholars have submitted definitions of technological capability. Fransman (1984) defines technology capability as the ability owned by a company to search and select appropriate technology; mastery of the technology chosen; the success of its use in the within production unit; the successful adaptation of the technology in specific production conditions and local demand; the achievement of incremental development; search important innovation through R\&D facilities; and conduct basic research. Bell and Pavitt (1995) define technological capability as the ability to mobilize and manage technical changes, including expertise, knowledge and experience, which are often substantially different from the 
requirement to operationalize existing technical systems.

Kim (1997) describes technological capacity as the ability to make effective use of technological knowledge in an effort to assimilate, use, adapt and change existing technologies, with the resulting expectations of technological developments, new products and processes to respond the changes in the economic environment. Meanwhile, Hobday \& Rush (2007) define it as knowledge, skills and organizational skills accumulated, which enable the company to acquire, develop and use technology to achieve competitive advantage. Both definitions refer to the importance of using knowledge as a central element of technological capability. The development of technological capability demonstrates an existence of ability and knowledge that can not be explained, recognized or easily (tacitly) transmitted. This shows that the learning process requires effort.

Figueiredo (2002) defines technological capability as the resource needed to generate and manage organizational improvement, production processes, products and equipment and engineering design. Other authors such as Morrison, Pietrobelli and Rabelloti (2008) consider that technological capability includes not only technical skills, but also other skills and organizational directive. Furthermore Lugones in Lopez-Salazar et al. (2014) asserts that technological capability can be seen from the following three things:

\section{1) Characterization of the main production processes}

Lopez-Salazar et al. (2014) suggest the characterization of the primary production process is visible from the kinds of products made by the company and the stages of the production process. It is also seen from the level of automation of the production process of a company.

\section{2) The position of technology used by companies compared to any other company}

Positioning technology is seen from the technology used by the company compared to its peers in the market.

\section{3) Number of owned intellectual property rights (IPR)}

The number of owned IPR is taken from the number of owned prototypes and registered patents, patents which are being registered, and prototypes in development.

Various definitions state the importance of using knowledge as a central element of technological capabilities. Differences in the body of knowledge accumulated in the company, how knowledge is used and how to improve knowledge are fundamental aspects for the accumulation of technological capability. Therefore, the development of technological capabilities implies the existence of abilities and knowledge that cannot be explained, recognized or easily (tacitly) transmitted, which implies a process of learning that requires a conscious effort (Whitfields, 2012).

The learning process used in this article is based on the approach of Hansen \& Ockwell (2014). They present two typologies of learning in building technological capability, namely learning within the company (intra-company) and learning outside the company (mediated). The intra-company learning process is the acquisition of new knowledge from various sources within the company. An example is a new investment project which provides a space for learning about the changes that occur in the modification of equipment and machinery; it happens continually on other projects as well. Another example is the process of trial and error in any solution to problems in each specific project. Learning also occurs through a variety of in-house training programs, either in the form of face-to-face or on-the-job training of employees.

Learning can also be conducted through the technical efforts undertaken by the company laboratory, $\mathrm{R} \& \mathrm{D}$, design and engineering division, and quality control unit (Jonker, Romijn, \& Szirmai, 2006). Intra-company learning also occurs in the pursuit of internal strategic objectives in acquiring new knowledge through sources in the company (Xie \& White, 2004; Scott-Kemmis $\&$ Chitravas, 2007). In addition, the use of the resources-based view in enhancing human resources in the companies is a key element in the development of technological capabilities 
(Mathews, 2002). In new companies, investment in R\&D companies and the establishment of cumulative technological capabilities become a key development to note (Cohen \& Levinthal, 1990).

External learning in company means its learning is mediated; however, it involves a number of ways in which knowledge is acquired and internalized into the organization through sources outside the company (Bell \& Figueiredo, 2012). The knowledge is obtained through close relationships between the company and other institutions, such as local universities, or recruitment from sources outside of the company. Close relationships with foreign companies may occur in the form of licensing agreements, joint ventures, technology cooperation, technical assistance, strategic alliances, and other forms of relationships between commercial enterprises that support the local economy. By facilitating the acquisition, assimilation and the possibility of increased foreign technology such as the relationship between transnational corporations bring an important source of "learning by interacting" with foreign and partners who have advanced technology (Amsden, 1989; Hobday, 1995; Mathews, 2006). Other sources of external learning that is mediated between companies can occur when a company interacts with local competitors-either through formal business, such as a partnership project, or from non-formal channels such as "learning through cheating and copying" as well as local labor turnover. Such spillover of knowledge in local companies or small companies may be the key sources of learning for new companies (Kesidou \& Romijn, 2008). Viotti (2002) emphasizes that in a new company, learning technology is largely confined to the absorption of existing technology obtained from abroad, especially from companies that are technologically advanced. It is important that the external foreign sources of knowledge cover a wide range of conceptual frameworks that address the dynamics of technical change in developing countries.

This study uses qualitative data collected through in-depth and semi-structured interviews with respondents from several milk processing companies from April to May 2015. Respondents are the directors or production managers of milk processing companies, and the chosen study sites are dairy companies in the provinces of Jakarta, West Java, Central Java and East Java. They are divided into the following groups:

1) Foreign and domestic investment companies

2) Medium and large-scale companies.

Furthermore, the technological capabilities of the companies were identified from: 1) the level of automation in the production process; 2) the technology used by the company as compared to the technology of its peers in the market; and 3) the number of prototypes that are owned, the number of registered patents, patents which are being registered and the prototypes.

The process of accumulation of technological capabilities of the companies can be one of two types, namely learning from within the company (intra-company) and learning from outside the company (mediated). These learning mechanisms can be seen in Table 1.

Table 1.

Typology of Learning Mechanisms Used by Companies in Developing Technological Capability

\begin{tabular}{|c|c|c|}
\hline & \multicolumn{2}{|c|}{ Type of learning mechanism } \\
\hline & Internal & External \\
\hline $\begin{array}{l}\text { Different } \\
\text { learning } \\
\text { mechanisms } \\
\text { used by the } \\
\text { company }\end{array}$ & $\begin{array}{l}\text { A process } \\
\text { to acquire } \\
\text { knowledge } \\
\text { through internal } \\
\text { activities }\end{array}$ & $\begin{array}{l}\text { A process to } \\
\text { acquire local } \\
\text { knowledge and/or } \\
\text { from abroad }\end{array}$ \\
\hline $\begin{array}{l}\text { Effort } \\
\text { intensity in } \\
\text { the utilization } \\
\text { of learning } \\
\text { mechanisms }\end{array}$ & $\begin{array}{l}\text { The level of } \\
\text { persistence } \\
\text { from human } \\
\text { and financial } \\
\text { resources } \\
\text { intended to } \\
\text { improve the } \\
\text { learning from } \\
\text { inside }\end{array}$ & $\begin{array}{l}\text { The level and } \\
\text { persistence } \\
\text { of human and } \\
\text { financial resources } \\
\text { intended to } \\
\text { improve the } \\
\text { learning from an } \\
\text { external source }\end{array}$ \\
\hline
\end{tabular}

Source: Hansen \& Ockwell (2014)

The study used qualitative data collected in multiple case studies in 25 companies. Respondents in the case studies were selected based on representation of the location, type of ownership of capital and the main product. Data shows that $93 \%$ of milk processing companies are located in the area of Java. Therefore, case studies were conducted of companies located on the island of Java: in the provinces of Yogyakarta, Jakarta, West Java, Central Java and East Java. This was 
done to obtain data describing the general conditions of the milk processing industry in Indonesia. To obtain comprehensive data, case studies were conducted through in-depth interviews with the director or production manager of the companies.

In relation to the location of the companies, most of the case studies were carried out in companies located in West Java (32\%) and East Java (28\%). Both locations are the center of the milk processing industry in Indonesia. Respondents were also a fairly representative sample if viewed by the type of ownership of capital, such as local companies (40\%), cooperatives (36\%), and foreign companies (24\%). If categorized by primary products, respondents of the case studies also appear to be representative. The majority of case study respondents were companies producing fresh milk/cream companies $(48 \%)$ and companies producing other dairy products $(24 \%)$. Meanwhile, the smallest group of respondents are ice cream companies (only $8 \%$ ). This is in accordance with the general conditions of the milk processing industry in Indonesia, which is dominated by companies which produce fresh milk/cream and other dairy products.

In addition, the data was also deepened through interviews with stakeholders. Therefore, this study conducted an interview with the Ministry of Industry, representative investigators of the milk processing industry, and the Indonesian Institute of Sciences, where some $R \& D$ activities focus on the development of dairy processing industry in Indonesia.

\section{RESULTS AND DISCUSSION}

Based on capital ownership, milk processing companies in Indonesia can be grouped into three types, namely: (i) cooperatives; (ii) local companies; and (iii) foreign companies. The results showed differences among the three company categories in technological capabilities and mechanisms for developing capabilities.

\section{A. Technology capabilities of milk processing industry in Indonesia}

The results of this study show variations in technological capabilities in the milk processing industry in Indonesia when categorized by ownership of company's capital. This is evident from the difference in the character of the production process, which is identified through the major product types, product marketing and the level of automation in the production machine; technology position compared to competitors; and ownership of intellectual property rights. Table 2 shows the differences in the three groups of dairy companies in Indonesia on every indicator of technological capability.

Companies that are members of cooperatives are generally household firms, which are smalland medium-scale. Some started from dairy farm cooperatives and successfully developed towards milk processing. The product range of cooperative dairy farms is dominated by fresh milk and sterilized, pasteurized milk. The main function of the dairy farm cooperatives is to manage fresh milk taken from dairy farms of community and distribute the milk to large-scale dairy processing companies located near the centers of animal husbandry. Some of the cooperatives process fresh milk into dairy products. The dominant product is pasteurized milk that is marketed directly for public consumption. In addition, the dairy farm cooperatives also produce other dairy products that include liquid yoghurt, butter and cheese by utilizing fresh raw milk originating from dairy farmers who are members of the cooperative.

The products of companies belonging to cooperatives are usually marketed directly to consumers and users of traditional markets in the surrounding areas. Their products have not been able to enter the modern market (supermarkets) because it cannot meet requirements, particularly the health requirements of BPOM (the Food and Drug Control Agency). Market distribution of products such as butter and cheese has managed to cross over out of the city, but the quantity is limited to certain markets such as small restaurants and hotels.

Unlike the dairy cooperatives, local dairy processing and multinational corporation firms in Indonesia produce more varied dairy products using more complicated and lengthy production processes and higher technology. Fresh dairy products (milk sterilization) in a cooperative generally only use pasteurization technology, 
Table 2.

Technological Capability of Milk Processing Industry in Indonesia Based on Capital Ownership

\begin{tabular}{|c|c|c|c|}
\hline \multirow{2}{*}{$\begin{array}{c}\text { Variables of } \\
\text { technology capabilities }\end{array}$} & \multicolumn{3}{|c|}{ Company category of milk processing based on capital ownership type } \\
\hline & Cooperative & Local company & Foreign company \\
\hline $\begin{array}{l}\text { Character of } \\
\text { production process: } \\
\text { types of products }\end{array}$ & $\begin{array}{l}\text { - Pasteurized milk } \\
\text { (liquid) } \\
\text { - Ice cream } \\
\text { - Yoghurt (liquid) } \\
\text { - Butter } \\
\text { - Cheese }\end{array}$ & $\begin{array}{l}\text { - UHT milk } \\
\text { - Milk powder (full milk } \\
\text { powder, infant formula) } \\
\text { - Sweetened, condensed } \\
\text { milk } \\
\text { - Ice cream } \\
\text { - Yoghurt (liquid and } \\
\text { viscous) } \\
\text { - Butter } \\
\text { - Cheese (cheddar, } \\
\text { - softcheese, etc.) } \\
\text { - Baby food from milk } \\
\end{array}$ & $\begin{array}{l}\text { - UHT milk } \\
\text { - Milk powder (full milk } \\
\text { powder, infant formula) } \\
\text { - Sweetened condensed milk } \\
\text { - Ice cream } \\
\text { - Yoghurt (liquid and viscous) } \\
\text { - Butter } \\
\text { - Cheese (cheddar, softcheese, } \\
\text { etc.) } \\
\text { - Baby food from milk }\end{array}$ \\
\hline $\begin{array}{l}\text { Character of } \\
\text { production Process: } \\
\text { level of automation }\end{array}$ & Mostly manual & $\begin{array}{l}\text { - Medium-scale } \\
\text { companies mostly } \\
\text { automatic } \\
\text { - Large-scale companies } \\
\text { fully automatic }\end{array}$ & Fully automatic \\
\hline $\begin{array}{l}\text { Character of } \\
\text { production process: } \\
\text { marketing }\end{array}$ & $\begin{array}{l}\text { - Local } \\
\text { - Some inter-city/ } \\
\text { island with a limited } \\
\text { quantity } \\
\text { - Only traditional } \\
\text { markets, } \\
\text { supermarkets are not } \\
\text { logged in } \\
\end{array}$ & $\begin{array}{l}\text { - National (traditional } \\
\text { markets and } \\
\text { supermarkets) } \\
\text { - Exports } \\
\end{array}$ & $\begin{array}{l}\text { - National (traditional markets } \\
\text { and supermarket) } \\
\text { - Exports }\end{array}$ \\
\hline $\begin{array}{l}\text { Technological } \\
\text { positioning compared } \\
\text { with competitors }\end{array}$ & Lower & Average to Higher & Higher \\
\hline $\begin{array}{l}\text { Ownership of } \\
\text { intellectual property } \\
\text { rights }\end{array}$ & Does not own any IPR & $\begin{array}{l}\text { - Medium-scale } \\
\text { companies do } \\
\text { not own any IPR } \\
\text { - Large-scale } \\
\text { companiesown some } \\
\text { IPR }\end{array}$ & Owns IPR \\
\hline
\end{tabular}

whilst local and foreign dairy companies already use Ultra High Temperature technology (UHT). In addition to producing UHT milk products, local and foreign dairy companies also produce other kinds of dairy products such as sweetened, condensed milk, powder milk and baby food. In addition to producing liquid yoghurt that cooperatives are able to produce, local and foreign dairy companies can also produce thick yoghurt with additional probiotics intended for health purposes. Cheese produced by local dairy company are also more varied, such as soft cheese and cheddar.
The difference between local and foreign milk processing companies is found in their products. Generally, domestic firms do not produce one type of product only, but also other types of product. Meanwhile, foreign companies usually focus on certain types of products only, or produce other types of products through a new subsidiary. Some local dairy companies also became subsidiary for foreign companies.

Different from dairy cooperatives, the market shares of local and foreign dairy companies are wider in that they cover the entire island, even in exports. The product quality of local companies 
has met the health standards of BPOM, so that their products can be found in traditional markets as well as supermarkets which already have wellestablished marketing networks. Because they have managed to export their products, it means that they are also able to meet the strict safety standards for food and beverage products from the importing country.

Local dairy industry consists of medium- and large-scale firms. There is a striking difference between the two in terms of product quality and market share. In general, products of mediumscale companies are not able to meet the health standards of BPOM. Therefore, marketing is still limited to the traditional market and has not been able to enter supermarkets, although still with a wider distribution to various cities and islands. Meanwhile, products of large-scale domestic companies have been certified by BPOM. They also have already met the eligibility of international health standards, so that most products are successfully exported to foreign countries.

The research also showed that there is a significant difference between cooperative, local and foreign companies in the use of technology. Limitations in production and market share have implications for the ability of cooperatives and medium-scale local dairy companies in the use of high technology in the production process. This affects the level of automation in the production process. The production process of dairy cooperatives are still largely done manually. Although they do use particular machines and apparatuses, there are still parts of the process that are done manually. The process of inserting and mixing raw materials in the production machine is still done manually by dairy cooperatives. When compared with other dairy cooperatives, conditions such as process technology is also in found in its competitors. Nevertheless, the level of process technology in cooperatives is relatively lower than that in domestic enterprises.

Different from cooperatives, local and foreign dairy companies already use advanced technology exceeding its competitors, or at least on par with their competitors in overseas companies which have high levels of automation. Furthermore, the production process technology used by domestic, large-scale and foreign companies is almost fully automatic, using state-of-the-art machines. They also have the ability to generate intellectual property rights (IPR) which is well-supported by R\&D units for the development of products and processes. Intellectual property generated by domestic and foreign dairy companies occur in the form of formulations or compositions within the content of dairy products. Ownership of intellectual property rights means that the owned intellectual property can not be produced by competitors and is proven to drive corporate performance.

Based on the above description, it can be concluded that the level of technological capability in dairy processing industry group is varied based on the type of ownership of the company. Milk processing companies in the form of cooperative farms have lower technological capability than domestic and foreign companies. The technological capability of local companies is higher than dairy cooperatives, but medium-scale local companies in particular still have lower technology capability than foreign enterprises. However, the technological capability of largescale local companies is equal with that of foreign companies.

\section{B. Mechanism of technology capability development in the milk processing industry in Indonesia}

Having identifed the levels of technological capability, this section will describe the efforts made into making the milk processing industry in Indonesia into the current level of technological capability. Technological capability can be enhanced through companies' efforts in accumulating knowledge, so that the enhanced technology can be implemented in the production process. Each company has its own strategy for enhancing its technological capability. The results showed differences in the mechanisms used to develop technological capabilities in the dairy processing industry. Each category of the milk processing companies (cooperatives, local and foreign companies) spares different amounts of effort and intensity in improving its technological capabilities. 
The development of technological capability in the dairy processing industry in Indonesia occurs through a mechanism of technological learning by the company. The intensity of technological learning can be seen from the amount of investment allocated by companies to conduct these efforts. The technological learning mechanism that occurs in the milk processing industry in Indonesia can be seen from companies' efforts in technology development, human resource development and R\&D activities. The category differences in these mechanisms are summarized in Table 3.

In the dairy cooperatives, the limited production and market share limits its technology development. Some dairy cooperatives in Indonesia have R\&D units, although they are still in corporated into the production units. Identification of technological needs in the dairy cooperatives in Indonesia are generally carried out through coordination between the engineering and production units. This process is also helped by large companies who become their customers. After the technology needs are identified, the company needs to decide where the technology can be obtained. In general, dairy cooperatives in Indonesia gain production machines in three ways. First, companies buy their own production machinery in the local market - high quality machines at reasonable prices. Secondly, through the $\mathrm{R} \& \mathrm{D}$ unit that is linked to production, companies create their own machines by imitating existing machines on the market. Third, especially for dairy cooperatives that become suppliers to large companies, most of the technology needs is fulfilled by the patronage of large companies. In order to maintain the quantity and quality of dairy products supplied by cooperatives, generally large companies supply machinery to the production division of dairy cooperatives through grants or the purchase of machinery, in which payment is made in stages. Nearly all of the high-tech production technology is obtained by cooperatives through this mechanism. This happens because they are driven by the limited investment ability.

Unlike the cooperatives, local dairy companies have a higher capability for technological development. In general, companies have committed to allocate a substantial budget for technological development. The budget covers the financing needs for technology identification, the search for technology resources and purchase of new technology. The needs for the development of technology usually come from production units which are then communicated to engineering and $R \& D$ units, which are separate units. Furthermore, it is the top management who decides whether those needs can be realized through the improvement of existing technologies or purchase of new technology. Improvements in the technology process and machinery is done in R\&D unit. However, large-scale local dairy companies generally prefer to buy new technology. One of the largest national dairy companies has even committed to allocate a large budget to buy new technology every year. As this implies, the company has always had leading milk processing technology compared to its competitors. This has a positive impact on company performance. Therefore the company is able to maintain its position as one of the largest milk processing companies in Indonesia.

When companies decide to buy a new engine for the development of technology, the next most important step is to search for technological sources. In relation to this, domestic dairy companies, especially large-scale ones, have a strong commitment. To obtain new technology which meet the specifications required, including the best quality and price according to the budget, companies generally allocate particular funds to actively participate in exhibitions of milk processing technology not only domestically but also overseas. Active participation in technology exhibitions is not only intended for purchases of new machinery. This is done regularly so that the companies obtain up-to-date information about the latest technological developments in milk processing. Local manufacturers can not produce current best-quality dairy processing technology. Therefore, local milk processing companies generally choose to import the technology.

Similar to local dairy companies, the majority of technology development of foreign companies located in Indonesia is done by importing 
Table 3.

The Mechanism of the Technological Capabilities Development of Milk Processing Industry in Indonesia

\begin{tabular}{|c|c|c|c|c|c|c|c|}
\hline \multirow{2}{*}{\multicolumn{2}{|c|}{$\begin{array}{c}\text { Technology capability } \\
\text { development mechanism }\end{array}$}} & \multicolumn{6}{|c|}{ Milk processing company type based on capital ownership } \\
\hline & & & Cooperative & & Local company & & Foreign company \\
\hline \multirow[b]{2}{*}{$\begin{array}{l}\text { Technology } \\
\text { development }\end{array}$} & Internal & 0 & $\begin{array}{l}\text { Identification of } \\
\text { technological needs } \\
\text { Technology } \\
\text { improvement and } \\
\text { imitation performed } \\
\text { by R\&D unit linked to } \\
\text { another unit } \\
\text { Purchase of new } \\
\text { machines }\end{array}$ & 0 & $\begin{array}{l}\text { Identification of } \\
\text { technological } \\
\text { needs } \\
\text { Improving } \\
\text { technology R\&D } \\
\text { unit performed } \\
\text { Purchasing a new } \\
\text { machine }\end{array}$ & $\begin{array}{l}0 \\
0\end{array}$ & $\begin{array}{l}\text { Identification of } \\
\text { technological needs } \\
\text { Minor improving } \\
\text { technology } \\
\text { undertaken by the } \\
\text { R\&D unit } \\
\text { Purchasing a new } \\
\text { machine }\end{array}$ \\
\hline & External & 0 & $\begin{array}{l}\text { Purchase of machinery } \\
\text { from local suppliers } \\
\text { Procurement } \\
\text { technology of } \\
\text { customers (large } \\
\text { companies) }\end{array}$ & ० & $\begin{array}{l}\text { Searching for } \\
\text { information and } \\
\text { technology from } \\
\text { foreign sources } \\
\text { Purchasing of new } \\
\text { machinery from } \\
\text { suppliers overseas }\end{array}$ & ० & $\begin{array}{l}\text { Major improving } \\
\text { technology will be in } \\
\text { the center of R\&D are } \\
\text { located int he parent } \\
\text { company } \\
\text { Purchasing of a new } \\
\text { machine decided by } \\
\text { the parent company } \\
\text { Searching for } \\
\text { information and } \\
\text { technology resources } \\
\text { which is supported } \\
\text { and carried by the } \\
\text { parent company } \\
\text { Purchase of new } \\
\text { machinery from } \\
\text { suppliers overseas }\end{array}$ \\
\hline \multirow[b]{2}{*}{$\begin{array}{c}\text { Human } \\
\text { resources } \\
\text { development }\end{array}$} & Internal & $\begin{array}{l}0 \\
\circ\end{array}$ & $\begin{array}{l}\text { In-house training } \\
\text { Providing incentives for } \\
\text { employees with good } \\
\text { performance }\end{array}$ & $\begin{array}{l}0 \\
\circ\end{array}$ & $\begin{array}{l}\text { Training } \\
\text { Providing } \\
\text { incentives for } \\
\text { employees with } \\
\text { good performance }\end{array}$ & o & $\begin{array}{l}\text { Training } \\
\text { Providing incentives } \\
\text { for employees with } \\
\text { good performance }\end{array}$ \\
\hline & External & ○ & $\begin{array}{l}\text { External training of } \\
\text { machine suppliers, } \\
\text { governments, and } \\
\text { customers (big } \\
\text { companies) }\end{array}$ & o & $\begin{array}{l}\text { Recruitment } \\
\text { of employees } \\
\text { conducted in } \\
\text { collaboration with } \\
\text { high schools } \\
\text { External training } \\
\text { of government, } \\
\text { party suppliers to } \\
\text { training abroad } \\
\end{array}$ & 0 & $\begin{array}{l}\text { External training from } \\
\text { suppliers, government } \\
\text { and organized and } \\
\text { supported by the } \\
\text { parent company } \\
\text { Expatriat of the parent } \\
\text { company as an expert }\end{array}$ \\
\hline \multirow[t]{2}{*}{ R\&D activity } & Internal & 0 & $\begin{array}{l}\text { Still minimal } \\
\text { Has the R\&D unit that } \\
\text { was linked to another } \\
\text { unit }\end{array}$ & 0 & $\begin{array}{l}\text { Routinely } \\
\text { conducted } \\
\text { Has the special } \\
\text { R\&D unit }\end{array}$ & ○ & $\begin{array}{l}\text { Not all conducted in } \\
\text { the company } \\
\text { Has the special R\&D } \\
\text { unit }\end{array}$ \\
\hline & External & 0 & $\begin{array}{l}\text { Cooperating with the } \\
\text { university but still done } \\
\text { personally }\end{array}$ & 0 & $\begin{array}{l}\text { Cooperating with } \\
\text { R\&D institutions } \\
\text { and universities }\end{array}$ & ○ & $\begin{array}{l}\text { Largely conducted in } \\
\text { the parent company }\end{array}$ \\
\hline
\end{tabular}


new machinery with different procurement mechanisms. In foreign companies, the supply of production machinery is very dependent on the parent company. A company is only required to identify the machine required and then submit it to the parent company. It is the parent company who has the authority to decide and carry out the procurement of new machines. Sourcing new technologies has generally performed by the parent company. There are two mechanisms that occur in foreign dairy companies in terms of technology development through these improvements. When the improvements are minor, then only the local $R \& D$ at the company is involved. However, major improvements are conducted by the $R \& D$ center at the parent company.

Improved technological capability in the dairy processing industry is also encouraged by the efforts of companies in improving human resource capabilities, including level of knowledge and skill. This is done through various efforts, including training and incentives for employees who have perform and achieve well. All of the dairy firms in Indonesia use training as a mechanism to improve the ability of its employees. Training is conducted in-house and externally. Striking differences can be seen in mechanisms contained in external training. In addition to training from the government and suppliers, employees of dairy cooperatives also receive training from customers that are large enterprises. Meanwhile, large-scale local companies actively send their employees to training abroad. All funding for the training can be covered by the company, but it can also be covered by sponsors. It is different for foreign dairy companies, where training is organized and supported by parent companies located abroad. In order to improve human resource capacity, parent companies also embed their human resources in Indonesia as experts in order to conduct knowledge transfer to the local human resources.

The mechanism of human resources development through the provision of incentives is found in almost all of the milk processing companies. Nevertheless, the administrated method is different in each company, in terms of the criteria given to incentivize employees such as the period and form of incentives. In general, incentives are given in the form of cash bonuses or opportunities for training abroad (especially in large-scale local companies and foreign companies). With regard to human resource development, there are also cases of large-scale domestic investment companies which use the mechanism of recruitment through cooperation with schools and universities. The best graduates from poor families are offered work positions by companies, and are then required to continue their higher education in a field related to a particular department assigned by the company. All financing, from of college until graduation is covered by the company.

Efforts to improve technological capabilities can be done through R\&D activities undertaken by the company. In the dairy processing industry in Indonesia, results of the study showed that $R \& D$ activities are intensively carried out by the companies themselves and become one of the key factors in technology development. However, mechanisms among the companies also differ quite noticeably. In the case of dairy cooperatives, some companies have $R \& D$ units, although it still belongs to the linked unit. This occurs because the dairy cooperatives' R\&D activities are still minimal and there is no specific budget allocation to do so. R\&D activities are carried out only when there is a need to undertake technology development. Technology improvement efforts are made through R\&D activities carried out in the R\&D unit. There are even cases of companies in dairy cooperatives whose $R \& D$ unit are capable of performing imitations of production machinery. These companies are able to create a prototype from which the production machine is later realized. Nevertheless, the produced simple, cloned machinery is limited for its own use and there are no plans for mass production. R\&D activities undertaken by the dairy cooperatives generally do not involve external parties. Even if the companies cooperate with local universities, it is still done personally by inviting one of the lecturers to conduct company visitations.

In contrast with companies in cooperatives, $\mathrm{R} \& \mathrm{D}$ activities in local companies are already sufficient. Local companies generally have their own R\&D unit with sufficient resources, both in personnel and budget. Therefore, R\&D activi- 
ties can be carried out routinely. All technology development is done through improvements generated in this unit. In fact, especially in largescale companies, local companies boost their R\&D activities by collaborating with domestic and foreign $R \& D$ institutions and universities. There are large companies that are committed to provide the full financing of $R \& D$ activities, but there are also companies that take advantage of the financing mechanism of the government. The high commitment of companies toward R\&D activities are driven by their belief that one of the key factors of performance dairy processing industry is the development of technology, which can be generated through $R \& D$ activities.

It is almost the same for foreign companies. However, the majority of $R \& D$ activities are carried out at $R \& D$ centers in parent companies, which are generally located abroad. Even some of the company's R\&D units exist only in the parent company and there is no R\&D unit in Indonesia. For companies with R\&D units, the units are generally only intended to carry out minor improvements. Meanwhile, major improvementsare still done at R\&D centers at parent companies.

Aside from the types of effort invested, increases in technological capability are also determined by the intensity of the effort invested. This can be measured by a company's commitment to invest in technology development, human resources development and R\&D activities. The results showed significant differences between milk processing companies according to their investments in the improvement of their technological capabilities (Table 4).

In the case of dairy cooperatives, the levels of production and marketing are still limited. This condition has implications for the limited investment in improving technological capability. Dairy cooperatives tend not to have a routine, specific budget allocation for technology development efforts. The budget will only be allocated if it is necessary. External support is also very limited. Generally, only customers who are large companies can provide investment support. It was only limited to supporting the procurement of new machines provided through grants or soft loans.

Different from the case of cooperatives, local and foreign dairy companies generally have a specific budget allocated regularly in large quantities for technology development efforts, human resources and R\&D activities. In the case of foreign dairy companies, the main source of investment comes from parent companies.

Therefore, the technology development of local and foreign dairy companies is done through the purchase of new machinery. One of the large-scale local companies is even committed to routinely allocate annual budget for the purchase of new machinery. This company is also willing to make large investments in $\mathrm{R} \& \mathrm{D}$ cooperation activities with R\&D institutions and universities abroad. This was done because the company believes that $R \& D$ activities is one of the key factors driving the competitiveness and performance of the company. The effectiveness of this strategy is evident from the position of the company, which has become one of the largest local milk processing companies in Indonesia. For domestic dairy companies, there are companies that take advantage of financing schemes from the government to conduct its R\&D activities. This has also been proven to increase technological capability.

\section{Table 4.}

Capability Technology Investment Development in the Dairy Processing Industry in Indonesia

\begin{tabular}{llll} 
& \multicolumn{2}{c}{ Milk processing company type based on capital ownership } \\
\cline { 2 - 4 } \multicolumn{1}{c}{ Sources } & \multicolumn{1}{c}{ Cooperative } & \multicolumn{1}{c}{ Local company } & Foreign company \\
\hline Internal & $\circ \begin{array}{l}\text { No specific budget } \\
\text { allocated }\end{array}$ & $\circ$ Special budget allocated & $\circ$ Special budget allocated \\
& $\circ \begin{array}{l}\text { Not routine: conducted as } \\
\text { it is needed }\end{array}$ & $\circ$ Routine & $\circ$ Routine \\
& $\circ$ Minimum & $\circ$ Large \\
& $\circ$ Customer support(large & $\circ$ Use of public funding & \\
\hline External & company) & schemes & The parent company \\
& & & became the main source \\
\hline
\end{tabular}




\section{CONCLUSION}

This paper analyzed how milk processing firms in Indonesia developed their technological capabilities. Some conclusions are proposed in this research paper. There are differences in the level of capability between cooperatives, local companies and foreign companies. Local and foreign companies produce a greater variety of products than cooperatives. In addition, local and foreign companies, using stages of the production process is further complicated by the high degree of automation, even closer to fully automatic. Both groups of companies would also have the ability to generate intellectual property rights (IPR) as supported by the special R \& D unit for the development of products and processes.

Differences also occur between the technological capability development mechanisms used. Technological capacity building is done by improving existing technologies and purchasing new machines. In cooperatives, technology improvement is the responsibility of an R\&D unit that was linked to another unit. However, funding of R\&D activity is still minimal and only carried out if necessary.

In local companies, technology improvement is undertaken by a specific R\&D unit. This unit allocate funds regularly in larger quantities. Meanwhile in foreign companies, minor technology improvement is performed by local R\&D unit, while major technology improvement is performed by the R\&D unit in the parent company.

All companies, whether cooperatives, local or foreign companies, use training mechanisms to improve the ability of human resources employees in different ways, especially in relation to external training. Cooperatives in particular follow external training financed by the government or large companies that become customers. Local companies actively send employees abroad for training at the companies' cost or find sponsors. Meanwhile in foreign companies, external training is supported by parent companies.

\section{ACKNOWLEDGEMENTS}

This article is an improved version of a paper that has been presented at 12th ASIALICS
International Conference in Yogyakarta on September 15-16, 2015 hosted by the Centre for Science and Technology Development Studies, Indonesian Institute of Sciences (LIPI). The author delivers deep gratitude to the participants for sharing discussions and comments to this paper.

\section{REFERENCES}

Amsden, A. (1989). Asia's next giant: South Korea and late industrialization. New York: Oxford University Press.

Basant, R., \& Chandra, P. (2002). Building technological capabilities in a liberalising economy: Firm strategies and public policy. Economics of Innov. New Techn., 11, 399-421.

Bell, M., \& Figueiredo, P. (2012). Innovation capability building and learning mechanisms in late comer firms: Recent empirical contributions and implications for research. Can. J. Dev. Stud., 33(1), 14-40. (http://dx.doi.org/10.108 0/02255189.2012.677168)

Bell, M., \& Pavitt, K. (1995). The development of technological capabilities. In U. Haque (Ed.), Trade, technology and international competitiveness. Washington: World Bank.

Centers and Agricultural Information. (2013). Buletin Konsumsi Pangan, 4(4).

Cohen, W.,\& Levinthal, D. (1990). Absorptive capacity: A new perspective on learning and innovation. Admin. Sci. Q, 35(1), 128-152.

Figueiredo, P. (2002). Learning processes features and technological capability accumulation: Explaining accumulation: Explaining inter-firm differences. Technovation, 22, 685-698.

Fransman, M. (1984). Technological capability in the Third World: An overview and introduction to some of the issues raised in this book. In M.Fransman \& K. King (Eds.), Technological capability in the Third World (pp. 3-30). London: Macmillan.

Hansen, U. E., \& Ockwell, D. (2014). Learning and technological capability building in emerging economies: The case of the biomass power equipment industry in Malaysia. Technovation, 34(10), 617-630. (http://dx.doi.org/10.1016/j. technovation.2014.07.003)

Herawati, T, \& Priyanto, D. (2013). Keragaan kinerja industri pengolahan susudalam mendukung swasembada susu di Indonesia. In Nurhayati D. P. et al. (Eds.), Prosiding seminar nasional teknologi peternakan dan veteriner 2013, 234-249. Jakarta: IAARD Press 
Hobday, M. (1995). Innovation in East Asia: The challenge to Japan. Cheltenham: Edward Elgar Publishing.

Hobday, M., \& Rush, H. (2007). Upgrading the technological capabilities of foreign transnational subsidiaries in developing countries: The case of electronics in Thailand. Research Policy, 36, 1335-1356. (http://dx.doi.org/10.1016/j. respol.2007.05.004)

Jonker, M., Romijn, H., \& Szirmai, A. (2006). Technological effort, technological capabilities and economic performance: A case study of the paper manufacturing sector in west Java. Technovation, 26, 121-134.

Kesidou, E., \& Romijn, H. (2008). Do local knowledge spillovers matter for development? An empirical lstudy of Uruguay's software cluster. World Dev., 36(10), 2004-2028.

Kjellstrom, E. (2000). Management assesment and control of intellectual capital. Department of Business Administrastion, Lund University, Sweden. Retrieved from: http://www.lri.lu.se/ pdf/crafoord00/e kws.pdf [March 10, 2004].

Kim, L. (1997). Imitation to innovation: The dynamics of Korea 's technological learning. Boston: Harvard Business School Press.

Lall, S. (1987). Learning to industrilize: The acquisition of technological capability by India. London: Macmillan.

Lall, S. (1992). Technological capabilities and industrialization. World Development, 20(2), 165-186.

Lopez-Salazar, A., Lopez-Mateo, C., \& Ruben, M. (2014). What determines the technological capabilies of the agribusiness sector in Mexico. International Business Research,7(10). (http:// dx.doi.org/10.5539/ibr.v7n10p47)

Mathews, J. A. (2002). Competitive advantages of the latecomer firm: A resource-based account of industrial catch-up strategies. AsiaPac. J. Manag., 19, 467-488.

Mathews, J. A. (2006). Dragon multinationals: New players in 21 st century globalization. Asia Pac. J. Manag., 23(1), 5-27.

Ministry of Agriculture. (2013). Statistik pertanian 2013 [Agriculture statistics 2013]. Jakarta: Pusat Data dan Sistem Informasi Pertanian, Kementerian Pertanian Republik Indonesia.

Ministry of Industry. (2014). Indonesia industry performance statistics. Retrieved from http:// www.kemenperin.go.id/statistik/kinerja.php. (February 6, 2015).
Morey, P. (2011). Dairy industry development in Indonesia. International Finance Corporation. Retrieved from http://www1.ifc.org/wps/wcm/ connect/93f48d00470e3bf883ffd7b2572104ea/ Dairy+ Industry+ Development-2011.pdf

Morrison, A., Pietrobelli, C., and Rabellotti, R. (2008). Global value chains and technological capabilities: A framework to study learning and innovation in developing countries. Oxford Development Studies, 36(1), 39-58 (http:// dx.doi.org/10.1080/13600810701848144)

Rasiah, R. (2009). Technological capabilities of automotive firms in Indonesia and Malaysia. Asian Economic Paper, 8, 151-169. (http:// dx.doi.org/10.1162/asep.2009.8.1.15)

Scott-Kemmis, D. \& Chitravas C. (2007). Revisiting the learning and capability concepts-building learning systems in Thai auto component firms. Asian Journal of Technology Innovation 15(2). (http://dx.doi.org/10.1080/19761597.2007.966 8638)

Sudaryanto. (2002). Sophisticated technology and Strategy: Analisis internal dalam menyusun integrated strategic planning pada technological-based business. Usahawan No.09 Th XXXI September 2002.Sunarharum, W.B., \& Santoso, I. (2012). Analisis kontribusi teknologi pada industri susu pasteurisasi di KUD DAU Malang [Analysis of the contribution of technology to the pasteurized milk industry at KUD DAU Malang]. J. Tek. Pert.,5(3), 141-150.

Viotti, E. (2002). National learning systems: A new approach on technological change in late industrializing economies and evidences from the cases of Brazil and South Korea. Technol. Forecast. Soc. Change, 9, 653-680.

Watanabe, C. 2004. Technological diversification as a key strategy for firm's sustainable development under mature economy. Tokyo Institute of Technology. Retrieved from http:arago.cprost. sfu.ca/ smith/conference/viewabstract.php?i $\mathrm{d}=797 \& \mathrm{cf}=4$

Whitfield, L. (2012). Developing technological capabilities in agro-industry: Ghana's experience with fresh industry pineapple exports. Journal of Development Studies, 48(3), 308-321. (http://dx.doi.org/10.1080/00220388.2011.63 5198)

Xie, W., \& White, S. (2004). Sequential learning in a Chinese pin-off: The case of Lenovo Group Limited. R\&D Manag., 34(4), 407-422. 